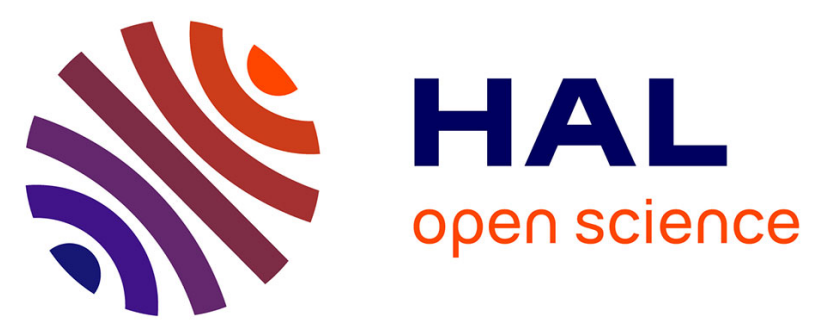

\title{
Mixture of Uncaria and Tabebuia Extracts are Potentially Chemopreventive in CBA/Ca Mice - A Long-term Experiment
}

Ferenc Budán, István Szabo, Timea Varjas, Ghodratollah Nowrasteh, Tamás Dávid, Péter Gergely, Zsuzsa Varga, Kornélia Molnár, Balázs Kádár, Zsuzsa Orsos, et al.

\section{To cite this version:}

Ferenc Budán, István Szabo, Timea Varjas, Ghodratollah Nowrasteh, Tamás Dávid, et al.. Mixture of Uncaria and Tabebuia Extracts are Potentially Chemopreventive in CBA/Ca Mice - A Long-term Experiment. Phytotherapy Research, 2010, 25 (4), pp.493. 10.1002/ptr.3281 . hal-00599836

\section{HAL Id: hal-00599836 https://hal.science/hal-00599836}

Submitted on 11 Jun 2011

HAL is a multi-disciplinary open access archive for the deposit and dissemination of scientific research documents, whether they are published or not. The documents may come from teaching and research institutions in France or abroad, or from public or private research centers.
L'archive ouverte pluridisciplinaire HAL, est destinée au dépôt et à la diffusion de documents scientifiques de niveau recherche, publiés ou non, émanant des établissements d'enseignement et de recherche français ou étrangers, des laboratoires publics ou privés. 


\section{Mixture of Uncaria and Tabebuia Extracts are Potentially Chemopreventive in CBA/Ca Mice - A Long-term Experiment}

\begin{tabular}{|c|c|}
\hline Journal: & Phytotherapy Research \\
\hline Manuscript ID: & PTR-10-0137.R1 \\
\hline Wiley - Manuscript type: & Full Paper \\
\hline $\begin{array}{r}\text { Date Submitted by the } \\
\text { Author: }\end{array}$ & 07-Jun-2010 \\
\hline Complete List of Authors: & $\begin{array}{l}\text { Budán, Ferenc; University of Pécs, Faculty of Medicine, Institute of } \\
\text { Public Health } \\
\text { Szabo, István; University of Pecs, Faculty of Medicine, Institute of } \\
\text { Public Health } \\
\text { Varjas, Timea; University of Pécs, Faculty of Medicine, Institut of } \\
\text { Public Health } \\
\text { Nowrasteh, Ghodratollah; University of Pécs, Faculty of Medicine, } \\
\text { Institute of Public Health } \\
\text { Dávid, Tamás; CoD Cancer Information \& Research Foundation } \\
\text { Gergely, Péter; University of Debrecen, Institute of Forensic } \\
\text { Medicine } \\
\text { Varga, Zsuzsa; University of Pecs, Faculty of Medicine } \\
\text { Molnár, Kornélia; Office of the Chief Medical Officer } \\
\text { Kádár, Balázs; University of Pecs, Faculty of Medicine } \\
\text { Orsos, Zsuzsa; University of Pécs, Faculty of Medicine, Institute of } \\
\text { Public Health } \\
\text { Kiss, István; University of Pecs, Faculty of Medicine, Institute of } \\
\text { Public Health } \\
\text { Ember, István; University of Pecs, Faculty of Medicine, Institute of } \\
\text { Public Health }\end{array}$ \\
\hline Keyword: & $\begin{array}{l}\text { Gene expression, carcinogenesis, chemoprevention, DMBA, Uncaria, } \\
\text { Tabebuia }\end{array}$ \\
\hline
\end{tabular}

\section{$\checkmark$ scholaroNE \\ Manuscript Central}


Mixture of Uncaria and Tabebuia Extracts are Potentially Chemopreventive in CBA/Ca Mice - A Long-term Experiment

\section{Correspondence to: Ferenc Budán} budfer2@gmail.com

Address: Szigeti str. 12, H-7624 Pécs, Hungary

Phone: +36-72-536-394

Fax: +36-72-536-395

\section{Experimental work}

Budán et al: Uncaria and Tabebuia are Chemopreventive in Long-term Mice Experiment

Key Words: Gene expression, carcinogenesis, chemoprevention, DMBA, Uncaria, Tabebuia 


\begin{abstract}
.
A long-term experimental animal model was developed by our research group for the evaluation of potential chemopreventive effects. The inhibitory effects of agents on carcinogen (7,12-Dimetilbenz[a]anthracene (DMBA)) induced molecular epidemiological biomarkers, in this case the expression of key onco/suppressor genes were investigated.

Expression pattern of $c$-myc, $\mathrm{Ha}$-ras, $\mathrm{Bcl}$-2, $\mathrm{K}$-ras protoonco and $\mathrm{p} 53$ tumoursuppressor genes were studied to elucidate early carcinogenic and potential chemopreventive effects. Consumption of so called "CoD ${ }^{\mathrm{TM}}$ tea" (abbreviation of Claw of Dragon tea) containing bark of Uncaria guianensis, Cat's Claw (Uncaria sp. U. tomentosa) and Palmer trumpet-tree (Tabebuia sp. T. avellanedae) was able to decrease the DMBA-induced onco/suppressor gene overexpression in a short-term animal experiment. In following study CBA/Ca mice were treated with $20 \mathrm{mg} / \mathrm{bwkg}$ DMBA intraperitoneally (ip.) and expression patterns of onco/suppressor genes were examined at several time intervals. According to the examined gene expression patterns in this long-term experiment the chemopreventive effect of $\mathrm{CoD}^{\mathrm{TM}}$ tea consumption could be confirmed.
\end{abstract}


In our previous studies a unique animal test model was developed through the investigation of onco/suppressor genes expression patterns, as molecular epidemiological biomarkers (Ember et al., 1998). 7,12-dimetilbenz[a]anthracene (DMBA) is a pluripotent and complete carcinogen, therefore it is applied to induce carcinomas in animal experiments. DMBA increases the expression of $c$-myc, Ha-ras, Bcl-2, $\mathrm{K}$-ras protoonco (Gyöngyi and Somlyai, 2002) and consequently p53 tumoursuppressor genes in the lungs and in the liver, as well (Sándor et al., 1995) in several animal species and also in both sex, indicating both carcinogenic exposure and early steps of tumour formation (Ember et al., 1998). The purpose was to study the early biological effect of DMBA and the protective effect of some potential chemopreventive agents in so called "CoD ${ }^{\mathrm{TM}}$ tea" (abbreviation of Claw of Dragon tea). Consumption of " $\mathrm{CoD}^{\mathrm{TM}}$ tea", which contains extract of Uncaria guianensis, Cat's Claw (Uncaria sp. U. tomentosa) and Palmer trumpet-tree (Tabebuia sp. T. avellanedae), was able to decrease the DMBA-induced overexpression of the genes mentioned above, in a short-term animal experiment (Orsós et al., 2007). According to pharmacological studies Uncaria species have cytotoxic, anti-inflammatory, antiviral, immunostimulative, antioxidant and antibacterial properties (Heitzman et al., 2005). Keplinger et al. confirmed that the pentacyclic oxindol alkaloides (POA) are the main biological active components of Uncaria species, which in vitro activate lymphocyte-proliferation regulating factor in endothelial cells (Laus et al., 1997; Keplinger et al., 1999). The bark of Palmer trumpet-tree is abundant in lapachol (2hydroxy-3-(3-methyl-2-butenyl)-1,4-naphthoquinone) (2-7\%), lapachone and xyloidone (de Santana et al., 1968), which are anticarcinogenic (Ueda et al., 1994) and inhibit the growth of the human keratinocyte cell line HaCaT culture in vitro (Müller et al., 1999). Our research group supposed that $\mathrm{CoD}^{\mathrm{TM}}$ tea consumption was able to decrease the overexpression of certain key onco/suppressor genes. 
In this long term study the effect of $\mathrm{CoD}^{\mathrm{TM}}$ tea was investigated on the expression of $c$-myc, Ha-ras, Bcl-2, $\mathrm{K}$-ras and $p 53$ onco/suppressor genes in CBA/Ca mice test model (Varga et al., 1991; Ember et al., 1992; Gyöngyi and Somlyai 2000).

\section{Materials and methods}

\section{Animals and Treatments.}

Infuse of $\mathrm{CoD}^{\mathrm{TM}}$ tea (D/Eu reg. numb.: PZN Deutschland: 4226037) was prepared according to the instruction of the manufacturer.

$10 \mathrm{~g}$ of the powder was suspended in $750 \mathrm{ml}$ tap water and left to soak for twelve hours, and then it was heated to $80{ }^{\circ} \mathrm{C}$ for thirty minutes. After filtration and water refill, the infuse was kept in a closed bottle avoiding light at $4{ }^{\circ} \mathrm{C}$.

$250 \mathrm{ml}$ extract is advised to be consumed three times a day, therefore the human dose is 0.167 g powder $/ \mathrm{kg}$ per os (calculated for $60 \mathrm{~kg}$ mean body weight).

Calculated equivalent dose for mice is $0.0033 \mathrm{~g}$ powder in $3 \mathrm{ml}$ tap water.

Quantity of total pentacyclic oxindol alkaloides (POA) is supposed to be $0.1-1.12 \%$, based on the results of Csapi et al. (Csapi et al., 2008).

Six- to eight-week-old $(20 \pm 4 \mathrm{~g})$ conventionally kept CBA/Ca inbred $\mathrm{H}-2^{\mathrm{K}}$ haplotype mice (6 males and 6 females in each group) were used for this experiment according to the following arrangement: control groups, DMBA treated groups, $\mathrm{CoD}^{\mathrm{TM}}$ consuming groups and DMBA treated groups with $\mathrm{CoD}^{\mathrm{TM}}$ consumption. These setups were measured at five time intervals after the first DMBA treatment: 1 week, 1 month, 3, 6 and 12 months later.

Control groups were given tap water and treated with ip. corn oil. DMBA treated groups received $20 \mathrm{mg} / \mathrm{bwkg}$ DMBA. (Sigma Aldrich Budapest, Hungary) dissolved in corn oil (Teva Pharmaceutical Industries Ltd. Debrecen, Hungary) intraperitoneally. DMBA treatment was applied at the beginning of the experiment and in addition two months later. 


\section{Gene expression investigations.}

One week, one, three, six and twelve months later the actual four groups were sacrified and their liver, lungs, kidneys and spleen were removed. $100 \mathrm{mg}$ tissue samples from each organ were collected, and samples of one group were pooled.

After homogenization of the organs, total cellular RNA was isolated using TRIZOL reagent (Invitrogen, Paisley, UK). The RNA quality was checked by denaturing gel-electrophoresis, and absorption measurement was performed at 260/280 nm (A260/A280 was over 1.8). After the necessary dilution, $10 \mu \mathrm{g}$ RNA was dot-blotted onto Hybond $\mathrm{N}^{+}$nitrocellulose membrane (ECL kit, Amersham, Little Chalfont, UK) and hybridized with chemiluminescently labelled specific probes for c-myc, Bcl-2, K-ras, p53 and Ha-ras (Professor J. Szeberényi, University of Pécs, Hungary) genes. Isolation of RNA, hybridization and detection were performed according to the instructions of the manufacturer. The membranes were rehybridized with the constitutively expressed beta-actin gene as a positive control. The chemiluminescent signals were detected on X-ray films, scanned into a computer and evaluated by Quantiscan software (Biosoft, Cambridge, UK). The results were expressed in the percentage of the positive control. (Data are shown in Figure 1-8.)

\section{Results}

In this study we investigated the level of certain onco/suppressor gene expressions. We found, that in the control group basal c-myc, Ha-ras, p53, Bcl-2 and $\mathrm{K}$-ras gene expressions vary both in time and in different organs. In the liver of male mice gene expression was low comparing to the beta-actin reference with a slight fluctuation (Figure 1.), in the lungs and kidneys (Figure 3, 5.) key onco/suppressor expression was higher with the same reference.

Compared to the results of male mice (Figure 1, 3, 5, 7.) we found, that in female mice (Figure 2, 4, 6, 8.) gene expressions were slightly lower nearly in every organ. Gene 
expression patterns of the liver were nearly the same (Figure 1, 2.), but in the lungs and in the kidneys expression was lower in female mice (Figure 4, 6.).

\section{The effect of DMBA treatment:}

DMBA caused the overexpression of the investigated key onco/suppressor genes. Male mice showed major elevations, especially in the lungs, kidneys and spleen (Figure 3, 5, 7.). In the lungs and kidneys these overexpressions decayed after one month but in the spleen key gene expressions remained high.

In the liver the key gene expression elevations were present - they were not as high as in other organs (Figure 1.). Moreover, at the $12^{\text {th }}$ month control major elevations were present. In the lungs, spleen and kidneys key gene expression elevations were detected.

In male mice highly increased key gene expression levels were measured in the lungs, kidneys and spleen (Figure 3, 5, 7.). In female mice similar - but milder - gene expressions elevations were detected in the organs mentioned above (Figure 4, 6, 8.).

In female mice major gene expression elevations were present at the $12^{\text {th }}$ month in every organ (Figure 2, 4, 6, 8.).

\section{The effect of $\mathrm{CoD}^{T M}$ on DMBA treatment:}

We compared the results of $\mathrm{CoD}^{\mathrm{TM}}$ tea consumption on DMBA treated mice to the DMBA induced overexpressed cases (positive control). In case of the DMBA we arbitrary chose more than $100 \%$ gene expression increase as overexpression, and in case of the $\mathrm{CoD}^{\mathrm{TM}}$ treatment we chose more than $100 \%$ key onco/suppressor gene expression decrease as major decrease in comparison to the positive control.

In Table 1. (male) and Table 2. (female) we highlighted the organs - and also the overexpressed genes - where major decrease were present.

Comparing to the DMBA treated group, $\mathrm{COD}^{\mathrm{TM}}$ tea consumption decreased onco/suppressor gene expression in the following cases: checking the one week control in the kidneys all of 


\section{Discussion}

The increase of $c$-myc, Bcl-2, K-ras, Ha-ras and p53 gene expression indicates early carcinogenic effects (Gyöngyi and Somlyai, 2002) and their overexpression is characteristic in certain manifest tumours. The amplification and overexpression of $c$-myc gene was found to exert an initiator role in human and in mice breast carcinogenesis as well (Dickinson et al., 1992). The activation and overexpression of Ha-ras protooncogene through point mutations was detected in colorectal carcinomas, as well (Csontos et al., 2008). Moreover Bcl-2 is an antiapoptotic gene, which is capable of causing immortalisation of tumour cells, especially if it is overexpressed (Norton and Atherton, 1998). The overexpression and activation of $K$-ras contribute to the formation of metastasis (Smakman et al., 2005) and enhances initiation and progression as well. 
The carcinogenic effect of DMBA in the lungs is well known (Stowers and Anderson, 1985), and correlates to our finding, because due to the treatment, all of the examined genes had increased expression in comparison to the control in both sexes. According to the gene expression patterns, $\mathrm{CoD}^{\mathrm{TM}}$ tea consumption in the lungs of male group seems to exert tumour formation inhibitory effect, usually as the results of several anticancer effects, such as anti-inflammatory, antioxidant (Heitzman et al., 2005) and DNA topoisomerase II partial inhibitory (Esteves-Souza et al., 2007) effects, as well.

Complete (both initiator and promoter) chemical carcinogens activate and overexpress Ha-ras proto-oncogene (Dickinson et al., 1992; Perjési et al., 2006), so the Ha-ras overexpression caused by DMBA correlates to these facts. Furthermore, $\mathrm{CoD}^{\mathrm{TM}}$ tea consumption decreased the overexpression of onco/suppressor genes induced by DMBA in the kidneys of male mice, presumably due to the result of antitumour properties of lapachone (Ueda et al., 1994) and inhibitory effects of POA on cancer cell proliferation (Lee et al., 2000).

Generally speaking, in male animals $\mathrm{CoD}^{\mathrm{TM}}$ tea consumption seemed to exert higher chemopreventive effect on carcinogen increased onco/suppressor gene expression, than in female groups. This could be explained with the noncompetitive, concentration-dependent oestrogen receptor binding property, and therefore oestrogen inhibitory effect of $U$. tomentosa's. But -according to the litarature- in long-term experiment, tamoxifen like paradox oestrogen enhancer effects were found (Salazar and Jayme, 1998).

Oestrogen receptor beta (ERbeha) is supposed to be effected (Bukulmez et al., 2008) by the oestrogen receptor activating effect of Uncaria extracts.

Anti-inflammatory activity of Uncaria extracts (Heitzman et al., 2005) is able to silence COX-2, thereby aromatase expression as well (Sirianni et al., 2009), leading to oestrogen level decreasing. Oestrogen level decreasing might slow the proliferation of certain sensitive cells (Sirianni et al., 2009). However, oestrogen increased the expression of Ha-ras - and 
consequently other oncogenes (Sándor et al., 1995) - in endometrial cancer cells via increasing tyrosine kinase (TK) activity (Fujimoto et al., 1995). Aromatase synthetize oestrogen in males dominantly, thus the inhibition of it underpins the higher efficacy of $\mathrm{CoD}^{\mathrm{TM}}$ tea in male groups, than in observed in female groups.

According to the expression patterns of the examined molecular epidemiological key onco/suppressor biomarker genes, in this long-term experiment the chemopreventive effect of $\mathrm{CoD}^{\mathrm{TM}}$ tea consumption could be confirmed.

\section{Acknowledgements}

The authors express their special thanks to Zsuzsanna Bayer and Mónika Herczeg for their valuable technical assistance. 


\section{References}

Bukulmez O, Hardy DB, Carr BR, Word RA, Mendelson CR. 2008 Inflammatory status influences aromatase and steroid receptor expression in endometriosis. Endocrinology. 149(3): 1190-204.

Csapi B, Csupor D, Veres K, Szendrei K, Hohmann J. 2008. Phythochemical analysis of Uncaria products commercially available in Hungary. Planta Medica 74: 1100.

Csontos Z, Nádasi E, Csejtey A, Illényi L, Kassai M, Lukács L, Kelemen D, Kvarda A, Zólyomi A, Horváth OP, Ember I. 2008. Oncogene and tumor suppressor gene expression changes in the peripheral blood leukocytes of patients with colorectal cancer. Tumori 94(1): 79-82.

Dickson RB, Salomon DS and Lippman ME. 1992. Tyrosine kinase receptor--nuclear protooncogene interactions in breast cancer. Cancer Treat Res. 61: 249-273.

Ember I, Kiss I and Pusztai Z. 1998. Effect of 7,12-dimethylbenz[a]anthracene on onco/suppressor gene action in vivo: a short-term experiment. Anticancer Res. 18: 445-447.

Ember I, Varga Cs, Herceg L, Raposa T. 1992. Szekunder tumorok állatkísérletes modellje. In vivo citosztatikus kezelési protokollok karcinogén-leukemogén hatása. Magyar Onkológia 46: 87-97. [Article in Hungarian]

Esteves-Souza A, Figueiredo DV, Esteves A, Câmara CA, Vargas MD, Pinto AC, Echevarria A. 2007. Cytotoxic and DNA-topoisomerase effects of lapachol amine derivatives and interactions with DNA. Braz J Med Biol Res 40(10): 1399-1402.

Fujimoto J, Ichigo S, Hori M, Morishita S, Tamaya T. 1995. Estrogen induces c-Ha-ras expression via activation of tyrosine kinase in uterine endometrial fibroblasts and cancer cells. J Steroid Biochem Mol Biol. 55(1): 25-33.

Gyöngyi Z and Somlyai G. 2000. Deuterium depletion can decrease the expression of $C$-myc Ha-ras and p53 genes in carcinogen-treated mice. In Vivo 3: 437-439.

Gyöngyi Z, Grama L, Nádasi E, Sándor J, Németh A, Varga C, Kiss I and Ember I. 2002. Flow cytometric analysis of DMBA-induced early in vivo ras expression. In Vivo 16: 323326.

Heitzman ME, Neto CC, Winiarz E, Vaisberg AJ, Hammond GB. 2005. Ethnobotany, phytochemistry and pharmacology of Uncaria (Rubiaceae). Phytochemistry 66(1): 5-29.

Keplinger K, Laus G, Wurm M, Dierich MP, Teppner H. 1999. Uncaria tomentosa (Willd.) DC. - Ethnomedicinal use and new pharmacological, toxicological and botanical results. J Ethnopharmacol 64: 23-34.

Laus G, Brossner D, Keplinger K. 1997. Alkaloids of Peruvian Uncaria tomentosa. Phytochemistry 45: 855-860. 
Lee JS, Kim J, Kim BY, Lee HS, Ahn JS, Chang YS. 2000. Inhibition of phospholipase cgamma1 and cancer cell proliferation by triterpene esters from Uncaria rhynchophylla. J Nat Prod. 63(6): 753-756.

Müller K, Sellmer A, Wiegrebe W. 1999. Potential antipsoriatic agents: lapacho compounds as potent inhibitors of HaCaT cell growth. J Nat Prod. 62(8): 1134-1136.

Norton JD, Atherton GT. 1998. Coupling of cell growth control and apoptosis functions of Id proteins. Mol Cell Biol. (4): 2371-2381.

Orsós Zs, Nádasi E, Dávid T, Ember I, Kiss I. 2007. Effect of $\mathrm{CoD}^{\mathrm{TM}}$ tea consumption in a „short-term" test system on the expression of onco- and tumor suppressor genes. Egészségtudomány 50: 195-107. [Article in Hungarian]

Perjési P, Ember I, Bozak RE, Nádasi E, Rozmer Z, Varjas T, Hicks RJ. 2006. Effect of the chalcone analog E,E-bis(2-hydroxybenzylidene) acetone on the 7,12dimethylbenz[a]anthracene-induced Ha-ras gene activity in vivo. In Vivo 20(1): 141-146.

Salazar EL, Jayme V. 1998. Depletion of specific binding sites for estrogen receptor by Uncaria tomentosa. Proc West Pharmacol Soc. 41: 123-124.

de Santana CF, De Lima O, D'albuquerque IL, Lacerda AL, Martins DG. 1968. Antitumoral and toxicological properties of extracts of bark and various wood components of Pau d'arco (Tabebuia avellanedae). Rev Inst Antibiot 8: 89-94.

Sándor J, Ambrus T and Ember I. 1995. The function of the p53 gene suppressor in carcinogenesis. Orv Hetil. 35: 1875-1883. [Article in Hungarian]

Sirianni R, Chimento A, De Luca A, Zolea F, Carpino A, Rago V, Maggiolini M, Andò S, Pezzi V. 2009. Inhibition of cyclooxygenase-2 down-regulates aromatase activity and decreases proliferation of Leydig tumor cells. J Biol Chem. 284(42):28905-16.

Smakman N, Borel Rinkes IH, Voest EE, Kranenburg O. 2005. Control of colorectal metastasis formation by K-Ras. Biochim Biophys Acta 1756(2): 103-114.

Stowers SJ, Anderson MW. 1985. Formation and persistence of benzo(a)pyrene metaboliteDNA adducts. Environ Health Perspect. 62: 31-9.

Ueda S, Umemura T, Dohguchi K, Matsuzaki T, Tokuda H, Nishino H, Iwashima A. 1994. Production of anti-tumour-promoting furanonaphthoquinones in Tabebuia avellanedae cell cultures. Phytochemistry 36: 323-325.

Varga Cs, Ember I, Raposa T. 1991. Comparative studies on genotoxic and carcinogenic effects of different cytostatic protocols. I. In vivo cytogenetic analyses in CBA mice. Cancer Letters 60: 199-203. 


\begin{tabular}{|c|c|c|c|c|}
\hline & Liver & Lungs & Spleen & Kidneys \\
\hline 1 week & $\mathrm{x}$ & $\begin{array}{c}c-m y c, \\
\text { Ha-ras, } \\
\text { p53, } \\
\text { K-ras }\end{array}$ & $\mathrm{x}$ & $\begin{array}{c}\text { c-myc, } \\
\text { Ha-ras, } \\
\text { p53, } \\
\text { Bcl-2, } \\
\text { K-ras }\end{array}$ \\
\hline 1 month & $c-m y c$ & $K$-ras & $K$-ras & $\begin{array}{c}c-m y c, \\
\text { p53, } \\
K-r a s\end{array}$ \\
\hline 3 months & $c-m y c$ & $\mathrm{X}$ & $\begin{array}{c}c-m y c, \\
\text { Ha-ras, } \\
\text { p53, } \\
\text { Bcl-2, } \\
\text { K-ras }\end{array}$ & $\begin{array}{c}\text { c-myc, } \\
\text { Ha-ras, } \\
\text { Bcl-2, }\end{array}$ \\
\hline 6 months & $\begin{array}{l}\text { Ha-ras, } \\
\text { p53 }\end{array}$ & $\mathrm{x}$ & $\mathrm{x}$ & $\mathrm{x}$ \\
\hline $\begin{array}{c}12 \\
\text { months }\end{array}$ & $\begin{array}{c}c-m y c, \\
\text { Ha-ras, } \\
\text { p53, } \\
\text { Bcl-2, } \\
\text { K-ras }\end{array}$ & $\begin{array}{c}\text { c-myc, } \\
\text { Ha-ras, } \\
\text { p53, } \\
\text { K-ras }\end{array}$ & $\begin{array}{c}c-m y c, \\
\text { Ha-ras, } \\
\text { p53, } \\
\text { K-ras }\end{array}$ & $\begin{array}{c}c-m y c \\
\text { Ha-ras, } \\
\text { p53 } \\
\text { Bcl-2 }\end{array}$ \\
\hline
\end{tabular}

Table 1. The effect of $\mathrm{CoD}^{\mathrm{TM}}$ on key onco/suppressor genes in male $\mathrm{CBA} / \mathrm{Ca}$ mice 


\begin{tabular}{|c|c|c|c|c|}
\hline & Liver & Lungs & Spleen & Kidneys \\
\hline 1 week & $\begin{array}{l}\text { p53, } \\
\text { K-ras }\end{array}$ & $\begin{array}{c}\text { Ha-ras, } \\
\text { p53, } \\
\text { K-ras }\end{array}$ & $\mathrm{x}$ & $\begin{array}{c}c-m y c \\
\text { Ha-ras, } \\
\text { p53, } \\
\text { K-ras }\end{array}$ \\
\hline 1 month & $\mathrm{x}$ & $\begin{array}{c}\text { Ha-ras, } \\
\text { Bcl-2, } \\
\text { K-ras }\end{array}$ & $\mathrm{x}$ & Bcl-2 \\
\hline 3 months & $p 53$ & $\mathrm{x}$ & $\mathrm{x}$ & $\mathrm{x}$ \\
\hline 6 months & $\mathrm{x}$ & $\mathrm{x}$ & $\mathrm{x}$ & $B c l-2$ \\
\hline 12 months & $\begin{array}{c}c-m y c, \\
\text { p53, } \\
\text { Bcl-2, } \\
K \text {-ras }\end{array}$ & $\begin{array}{c}c \text {-myc, } \\
\text { Ha-ras, } \\
\text { p53, } \\
K \text {-ras }\end{array}$ & $\begin{array}{c}c-m y c, \\
\text { Ha-ras, } \\
\text { p53, } \\
\text { Bcl-2 }\end{array}$ & $\begin{array}{c}c-m y c \\
\text { Ha-ras } \\
\text { p53, } \\
\text { Bcl-2 }\end{array}$ \\
\hline
\end{tabular}

Table 2. The effect of $\mathrm{CoD}^{\mathrm{TM}}$ on key onco/suppressor genes in female $\mathrm{CBA} / \mathrm{Ca}$ mice 


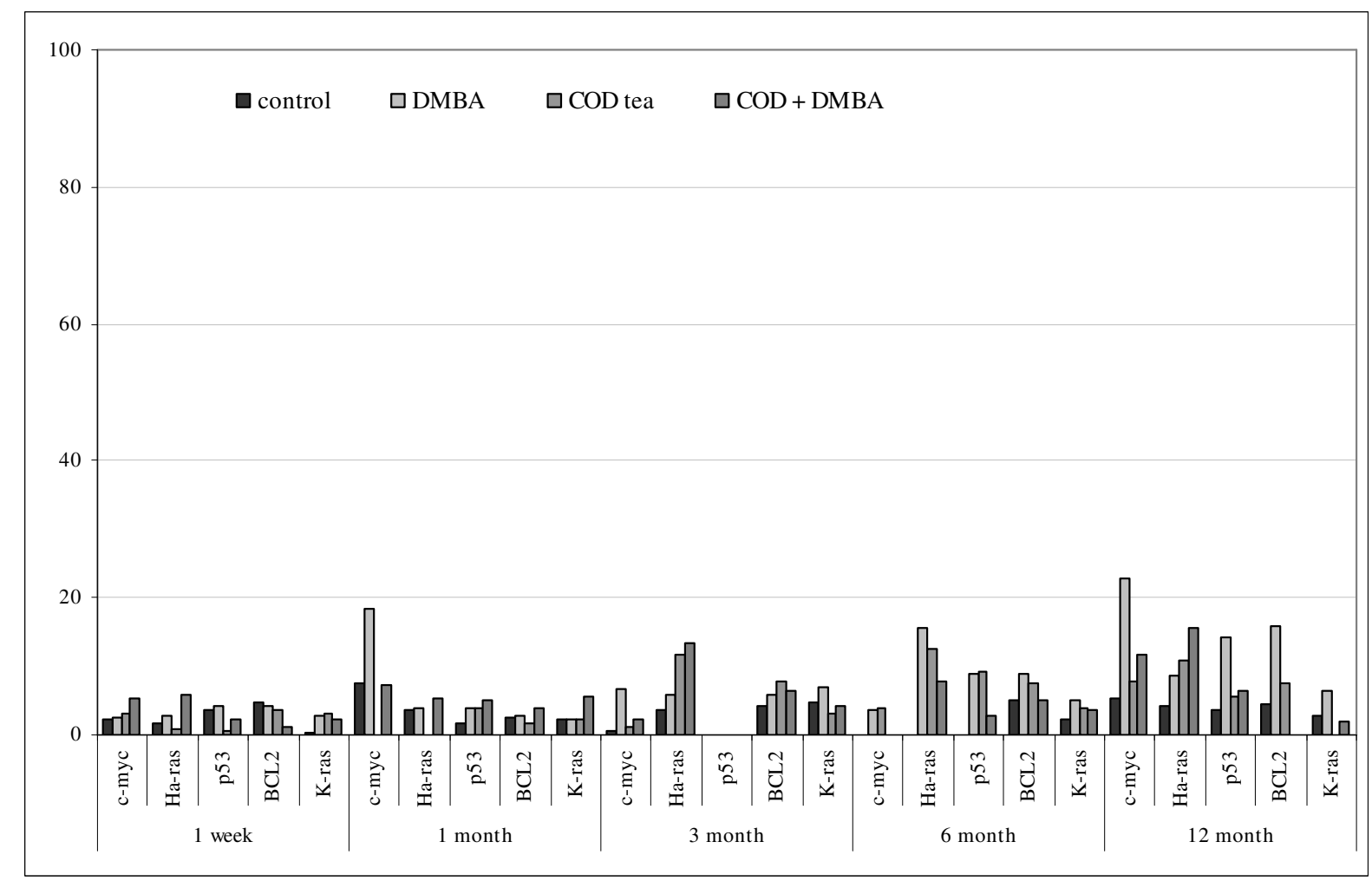

Figure 1. The gene expression profile of liver of male CBA/Ca mice 


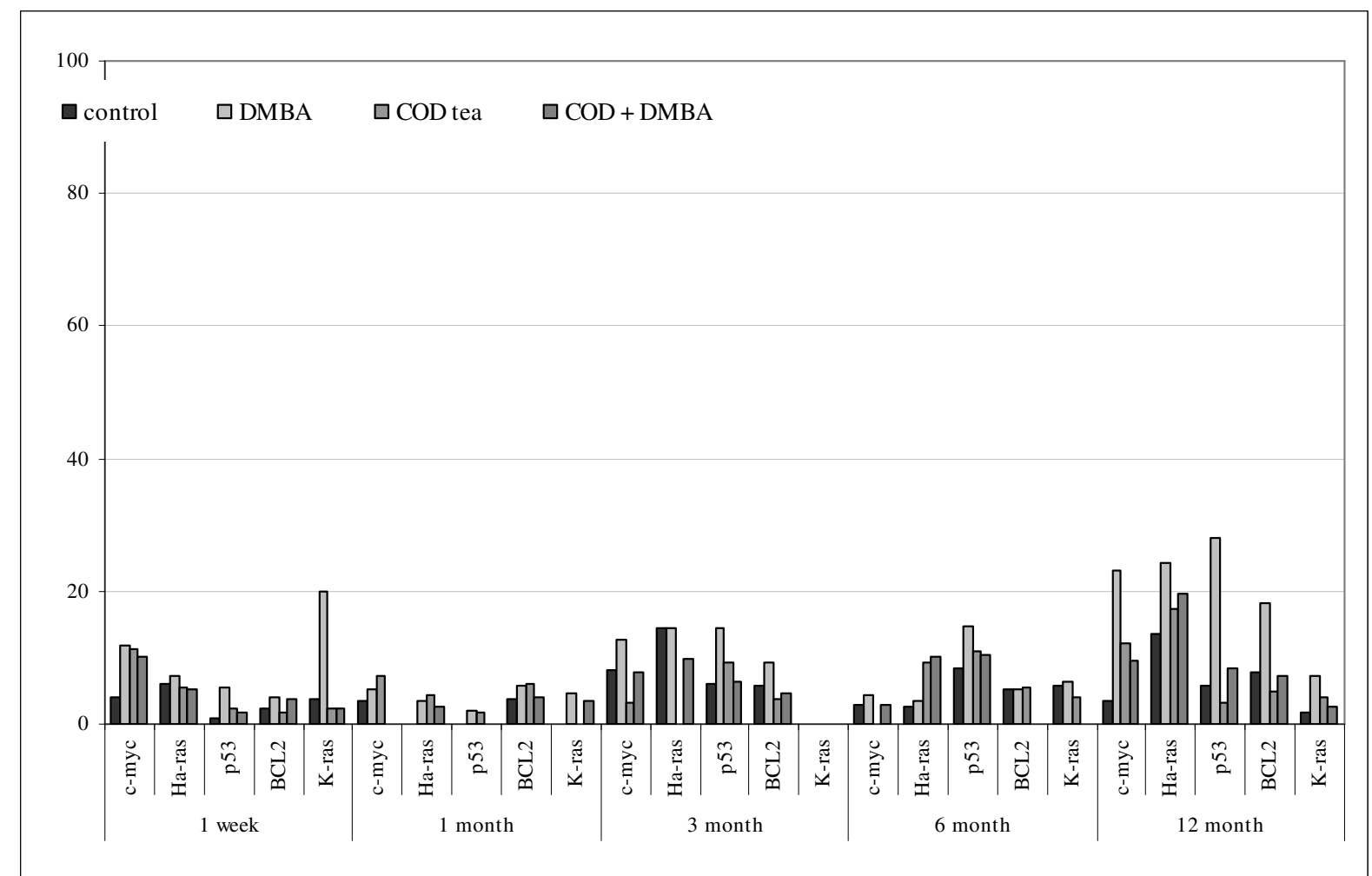

Figure 2. The gene expression profile of liver of female CBA/Ca mice 


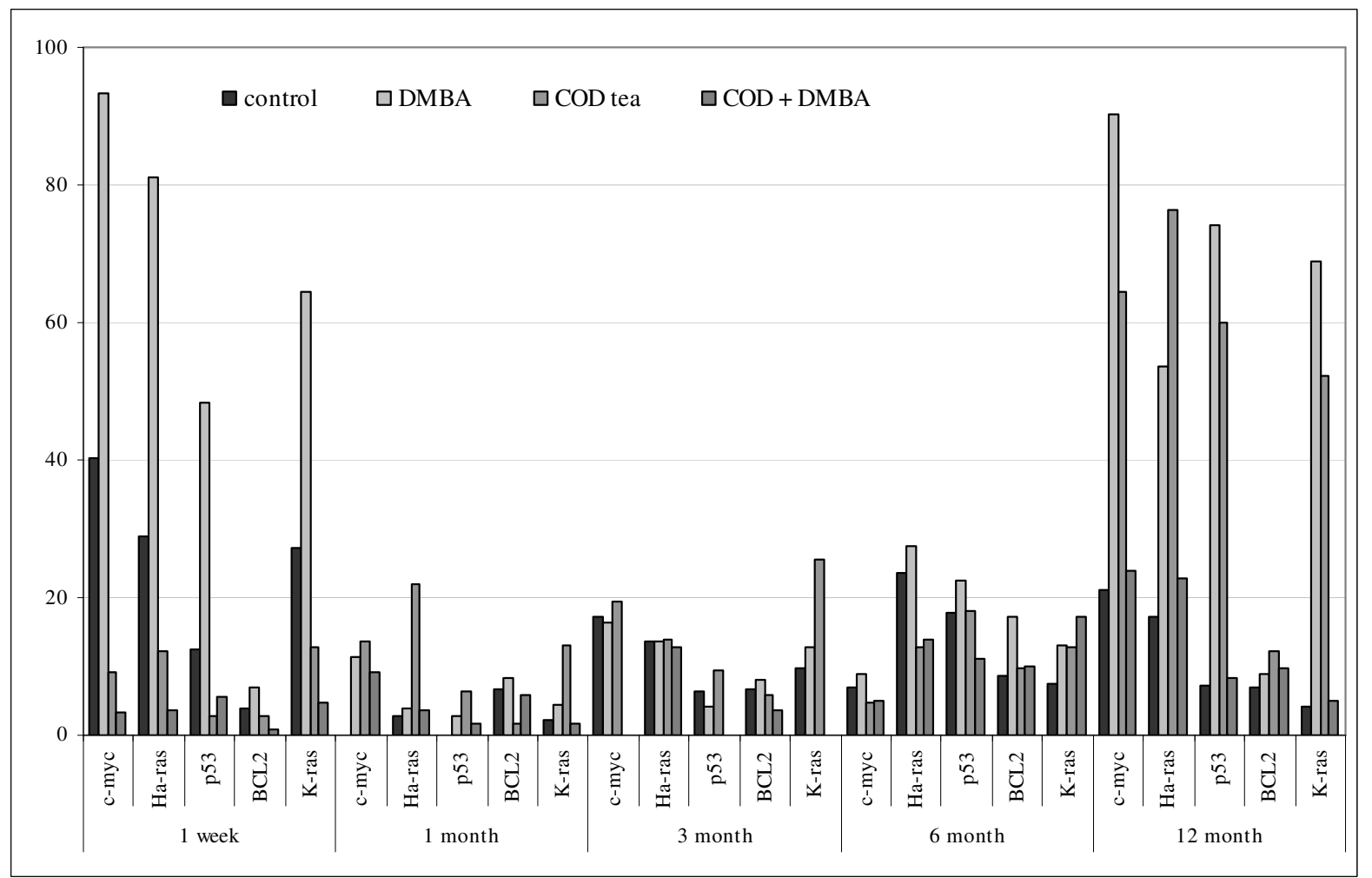

Figure 3. The gene expression profile of the lungs of male CBA/Ca mice 


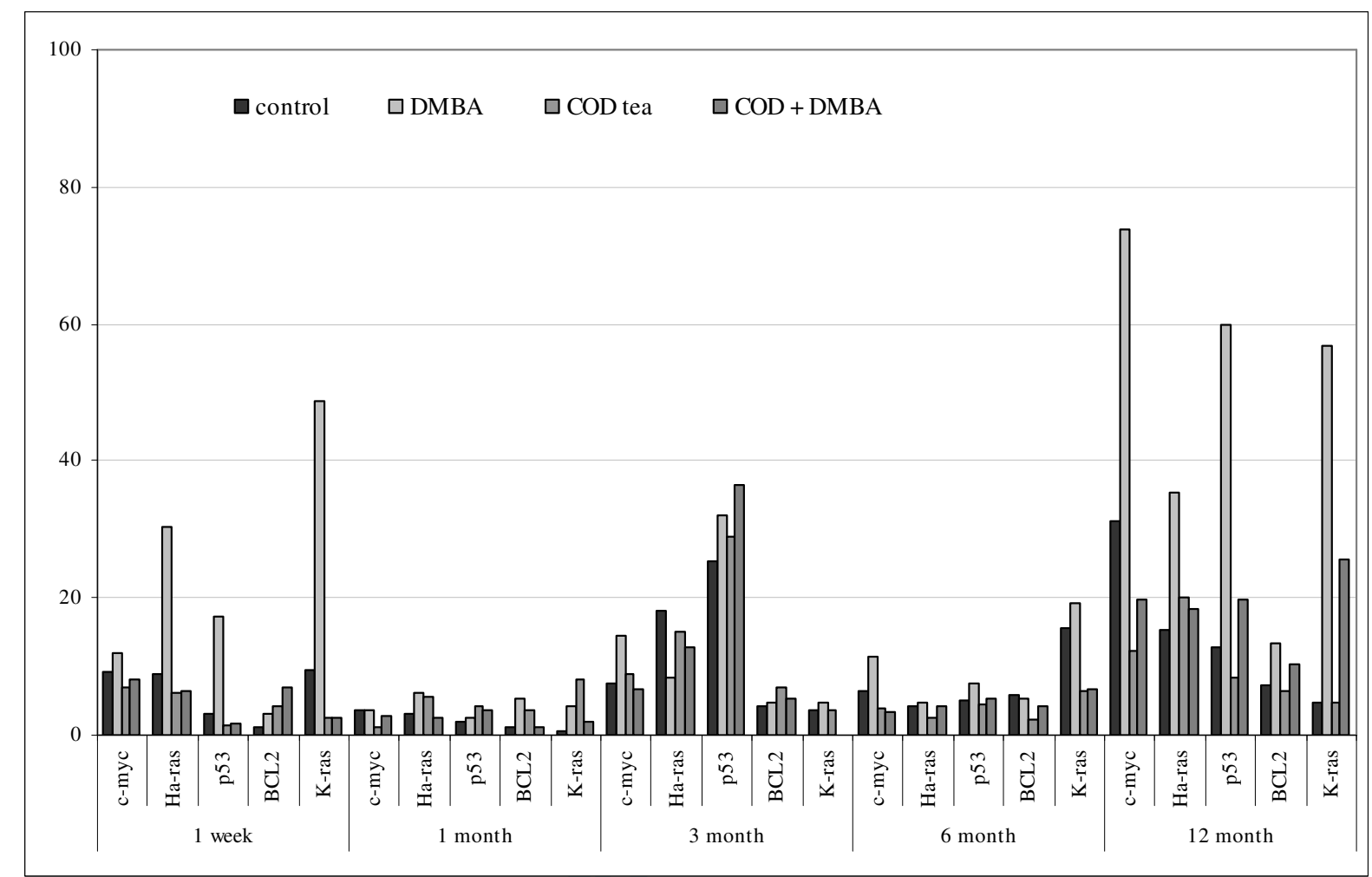

Figure 4. The gene expression profile of the lungs of female CBA/Ca mice 


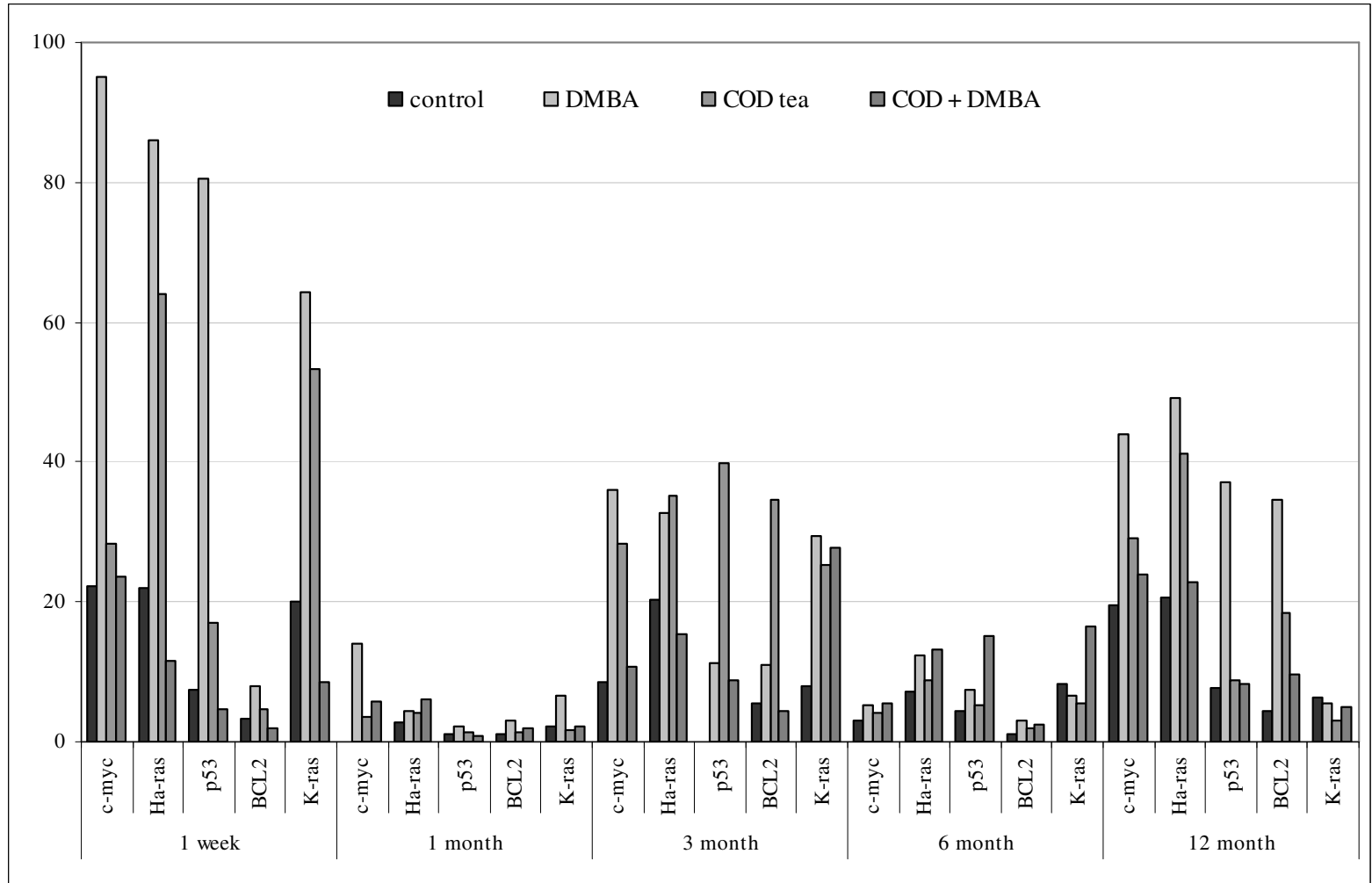

Figure 5. The gene expression profile of the kidneys of male $\mathrm{CBA} / \mathrm{Ca}$ mice 


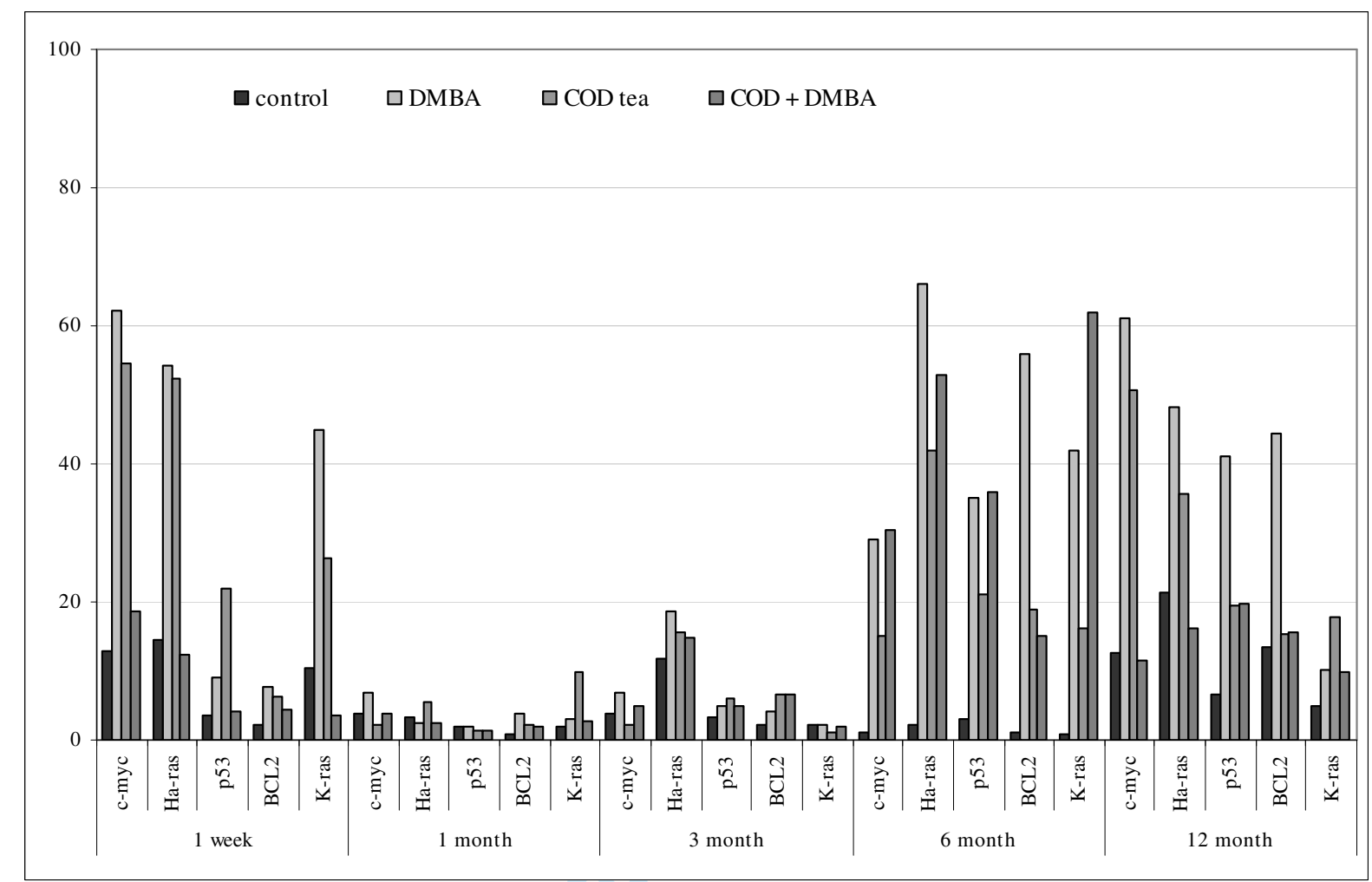

Figure 6. The gene expression profile of the kidneys of female $\mathrm{CBA} / \mathrm{Ca}$ mice 


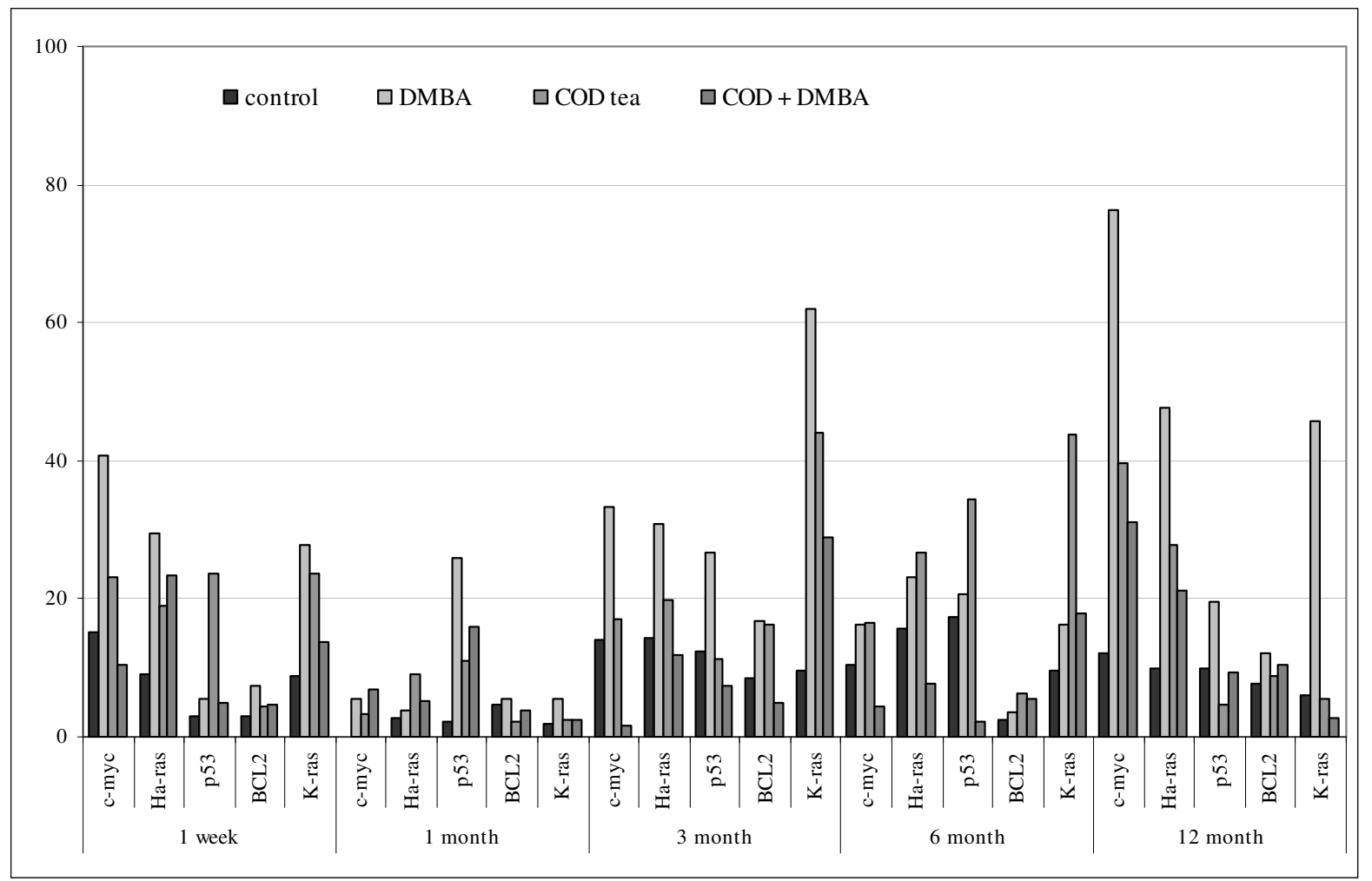

Figure 7. The gene expression profile of spleen of male CBA/Ca mice 


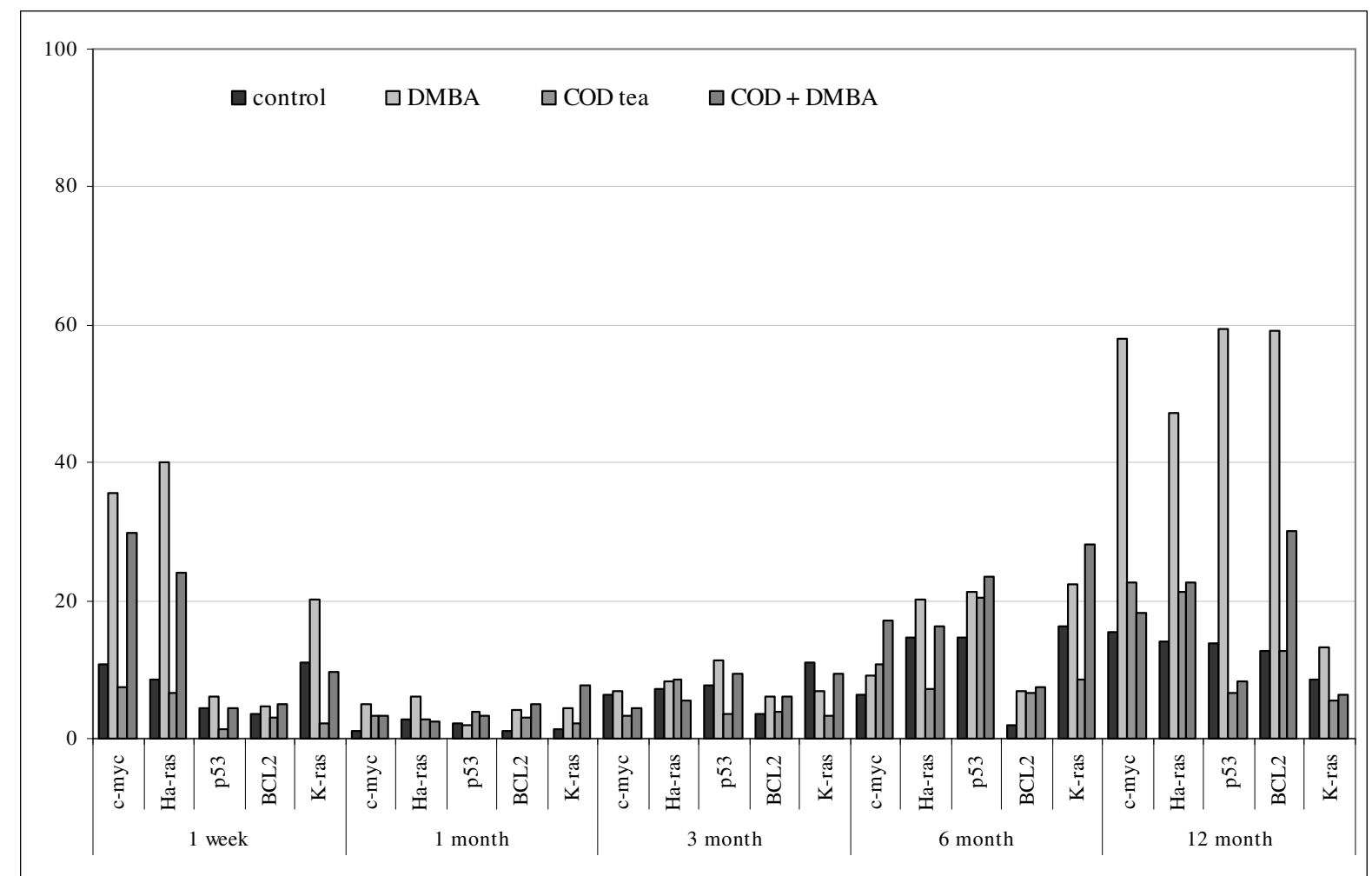

Figure 8. The gene expression profile of spleen of female CBA/Ca mice 